Journal of Social and Development Sciences

Vol. 3, No. 2, pp. 47-58, Feb 2012 (ISSN 2221-1152)

\title{
Impact of On-Job Training on Performance of Telecommunication Industry
}

\author{
*Nadir Khan, ${ }^{* *}$ Sayed Fayaz Ahmed, Muhammad Ibrahim, Muhammad Khalil Shahid \\ Institute of Communication Technologies, NWFP University of Engineering \& Technology, Peshawar, Pakistan \\ *nadirkhan.hoti@gmail.com \\ **fayaz_sayer@yahoo.com
}

\begin{abstract}
This research is about On-Job training and Performance of organization. It discusses the importance of training and its output, which is very necessary for individual performance and over all organizational performance. In this research study, various variables, which are the outcome of Training, have been taken into account. Further, more the relationship of all those variables with the over all organizational performance has been studied. A structural model has been developed according to the results and relationship of these variables. The research will add a significant figure to the performance of organization and will raise the importance and value of training in organizations. The results are applicable to all type of organizations and will help managers to make their firms more productive and stable.
\end{abstract}

Key words: On-Job Training, Promotion Opportunity, Individual Job Performance, Return on Training Investment, Employees Turnover and Productivity and Overall Organizational Performance

\section{Introduction}

Most of the employees come to organizations having an academic degree but no knowledge and skills about the job. They are very new at workplace and having no familiarity with it. Due to this situation, these workers needs further training to face their workplace in a well and easy way and perform better; and for this purpose training is planned to give them a specific knowledge and skills about their jobs (Fitzgerald, 1992). Some time older employees also need training in addition to their previous job skills because the new technology brings new jobs and responsibilities; and they need to get familiar with that. Training is not an easy way as it seems but it requires a huge investment of money in human capital. It has many advantages like creating competitive return for a firm, innovations, chances of learning about new technologies, improving and developing employee skills and hence increases the firm over all performance (Salas \& Cannon-Bowers, 2001). Some researchers have been criticized the training process as more expensive as it requires a lot of money and time (Kraiger, McLinden \& Casper 2004), and there is a doubt that whether it really a positive relationship between training and firm performance (Alliger, Tannenbaum, Bennett, Traver, \& Shortland, 1997; Wright \& Geroy, 2001). These days most of the firms in the developing countries are adapting new technologies and new jobs for various purposes like competition etc. They have pointed out that new skills and knowledge is necessary for the maintenance of their firms. Therefore, they are continuously investing money in the human capital and their bosses are trying to understand the basics of this investment and remain competitive in the market. Some organization start to train their employees when they recruit them formally like schooling and simultaneously keep them update either through on-the-job training or out side the job training (Carneiro and Heckman, 2003). We are trying to model not only the relationship of training and organizational performance but also found out the rate of training investment linking with firm performance for the first time in telecom sector in Pakistan.

Highly educated employees demand high salaries and other incentives, which may be an extra burden over the economy of the organization. Most of the employees left the organization due to no motivation, promotion or due to incompetence to work, mostly those having weak background. To develop the status of the employees and organization, managers provide training and development to the employees, which in turn create the issues of Return on Investments. Senior managers need to show the return on their training investment to the upper management. Competitive economic pressures are causing intense scrutiny of all expenditures, including all training and development costs. For the above-mentioned need an organization 
also needs to fined out how this training given to an employee or worker returns to the institution he belongs. This research will find out the main variable arias from on the job training and its effect upon the performance of the telecom industry. The main objectives of this research are:

- To find out the importance of Job Training and Performance of Telecom Industry.

- To find out the effect of Job training on some important variable leading to Performance of Telecom Industry.

- To find the return of the training investment to the organization.

- To find out a way to increase the Performance of telecom Industry.

- To design a model for Job Training and Performance of Telecom Industry.

The result will be significant to Increase the performance of the organization and Help managers to maintain a proper way of training in order to attain the organization's objectives. The result may be utilized in the areas where an organization has low competent employees also the result may also be used by the managers to identify the main effecting variables, which are helpful for the performance of the organization. It will give the manager an idea how and how much investment should be used to train the employees and get a valuable return on their training investment.

\section{Literature Review}

Now days, there is a rapid and continuous development in the areas of technology and innovation, and each organization is facing the ultimate need for its employees training and development to accept and face the modern challenges of competitive world. For the above reason we have conducted the literature review.

On-the-job Training: Every organization contains managers, supervisors and other executives. Organization hires new employees, who are not competent in their job and train them to perform better and better. Organizations also contain such employees who are senior in their jobs but could not fulfill the need of modern technology so organization gives them training on the various problematic areas to them. The developing process of employees' skills in order to improve the performance is called training (Swanson, 1999). Senior workers of an organization can have a strong positive impact on training (Jong, Leenders and Thijssen, 1999). Usually training adds directly to the human resource development and performance of the organization. Organization needs to analyze the job performance, find out the problematic areas, and then train the respective employees with the special training programs. Human resource development focuses on the training to solve organizational issues and develop technical knowledge, interpersonal skills, social dealing and other skills set of its employees (Kuchinke, 1996). On the job training are commonly used for educating the employees of organization at all level. The aim of this training is get aware the employees with new practices or promote the sills of the workers related to a specific job. This type of training is usually done under established standards (Vaught, Hoy and Buchana, 1985). Common methods of OJT include job rotation and assignments. Both of the methods are applied to the employees in order to learn technical and managerial skills. Skills needed to problem solving and interpersonal are mostly obtained effectively and efficiently by the employees through Off Job training (VanWart, Cayer and Cork, 1993). In summary, training is planned to develop and promote the skills and knowledge of the present job of employees (Fitzgerald, 1992). On one side, Training investment creates competition for organization but can also offers innovations and chances to get better employee skills and improve firm's performance (Salas \& Cannon-Bowers, 2001). Most of the organizations know that training investment could improve productivity and decreases turn over of employees (Huselid, 1995; Salas \& Cannon-Bowers, 2000).

Promotion Opportunities: As there is the rule of new technology and a trend of globalization now days in the market place, making the market more competitive and productive, also warns each organization to face the competition and make itself more productive in order to maintain its market place and existence. Due to this technological transition of modern age, organization not only invests money in new and modern machinery but also invest a lot in human capital through training, to get aware them with job specific skills for the risen of worker's productivity. There are two main types of strategies, according to the first one; employers select low-wage low-cost strategy to be in completion. Secondly, employers trust that productivity 
is increasing through advanced skills and training (Holzer, 2007a). Employers are also facing difficulties in attracting and keeping skilled employees, mostly on the high paying position needing various training after high school degrees but having less education than bachelor's degree (Holzer \& Lerman, 2009). Employers must also fill the positions left vacant after the retirement of a senior worker with another worker (Dohm, 2000). This phenomenon also increases and maintains the firm productivity due to skilled and happy workers. These issues have only the solution to invest in keeping skilled workers, which result and plan a note worthy job advancement (Dohm and Shniper, 2007). Training is a need of low skilled employees for their job growth, which is directly related to their financial outcome (Holzer \& Martinson, 2005). One research that is more recent also supports this concept (Macguire, Freely, Clymer, \& Conway, 2009). There are some other researches, which also support the original concept of training linking with wage growth (Lynch, 1992). After taking the above literature study, we guess the following two hypotheses.

H1: On-job-training has a positive effect on the employee's job advancement.

H2: Job advancement has a positive relationship with Organization's over all performance.

Individual Job Performance: In today's competitive environment, human capital has increasing its importance day by day due to the competition and performance of firms. This increase in importance results an increase in the companies training investment to improve the employee abilities and skills (Lev, 2001). The main goal of these training investments is to enhance the performance of employee by enhancing the organizational work skills. Some researches were also made to evaluate its organizational level return systematically (Dearden, Reed, and Reenen, 2006; Zwick, 2006). On the other hand, there are also exist studies which focus the training effect on employee performance individually (Veum, 1995; Parent, 1999). Even tough, the only way to improve and accumulate the employee skills is On-the-job training, but it is also clear that so much expenditure in training also needs an analysis between its cost with benefits and employees performance. A number of studies argue that training may show the way of improved and better performance but it is only the single part of HR practices (Arthur, 1994; Huselid, Jackson, and Schuler, 1997). As training is giving to employees for the improvement of specific job skills before it may increase the organizational level performance. This means that whether the learned skills and abilities are fruitful for the job or not. In other words if the training increases the job related abilities, it should increase the job performance of individual (Salas, Cannon-Bowers, Rhodenizer, and C. Bowers, 1999). We are trying to find out the actual result whether the training increases individual performance or not on individual level. Our giving concept is very different from the previous studies in with they used field analysis by relating the performance growth with the increase of wage (Lynch, 1992; Barron, Black, and Loewenstein, 1993); Parent, 1999) yet this research is also field survey. We assume the following relationships between on-the-job training, individual performance and over all organizational performance which have been supported by the literature survey.

H3: On-job-training has a positive effect on individual job performance.

H4: Individual job performance has a positive relationship with Organization's over all performance.

Employees Turnover: Human resource and development focally develop such a tradition in an organization, which encourage learning (Watkins \& Marsick, 2003). There are also some additional attitudes of job, which have a strong impact on organizational learning environment like job satisfaction, organizational commitment and motivation (Kontoghiorghes, 2001). Learning Organizational environment has a strong effect on motivation of employees to transfer knowledge (Kontoghiorghes, 2001) and employee attitudes has a potential relation with environmental attributes that effects satisfaction of job and intent to turnover (Gaertner, 2000). In addition, intent to turnover is inversely related to job satisfaction (Sablynski, Lee, Mitchell, Burton, \& Holtom, 2002). Increased in turnover of employees decreases other employees productivity as they play the role of a mentor for the new ones (Cascio, 2000). Job satisfaction is increased by the efficient communication of supervisor (Kim, 2002). In addition, trainee's interests, attitudes, behavior and expectations influence the effectiveness of training (Noe, 1986). Another study stated that when trainees are engaged in learning activities and training in which they learn form their seniors is compulsory, it was reported that there are stronger intentions of transfer in such a situation (Baldwin, Magjuka, and Loher, 1991). Employees are more happily participate in that training when they perceived that it is related to their job (Baumgartel and Jeanpierre, 1972). As turnover intention has a great affect over the productivity of organization, it remained the core area of research for some time and yet it is, and they found that it is 
inversely proportional to the job satisfaction (Sturman, Trevor, Boudreau, \& Gerhart, 2003). This inverse relation relationship has been supported by several more studies (Trevor, 2001). Therefore, most of the employees left the organization due to some important attitudes relating to job. Among them, job satisfaction is the most important and deserves to be taking into account here. Therefore if there is proper on-job-training of employees and a culture of learning, it will increase the job satisfaction of employees and lessen will be the turnover rate. In addition, through proper training, an organization may decrease the difference between the less educated and high educated employees, which are also helpful to decrease the rate of turn over. In addition to this, the organization will maintain its normal operations with old and trained employees, in which the seniors help the juniors or less competent employees and so less will be the expenditure of hiring and recruiting new employees. This will increase the overall performance of the organization. The above literature survey directs us to write the following hypothesis.

H5: On-job-training has a negative effect on employees' turnover.

H6: Employees' turnover has a negative relationship with Organization's over all performance.

Productivity: Organizations invest a lot of money in training to increase productivity of organization but there is a limited research on this topic in Pakistan. In December 2003, training has been warranted by the British Chancellor for the sake of productivity and skill improvement among the employees. Although the issue is more important, yet the research addressing the relation of productivity and training is in small amount. One of the researches discusses objective measure of productivity (Ballot, Fakhfakh, and Taymaz, 1998); some of them apply productivity subjective measure (Krueger and Rouse, 1998). Even though there is a positive relationship between training and productivity gain, the interpretation is not so easy due to the one time or one point investment in training, which could also get up some other unobservable organizational factors associated with productivity and training. A research was done to measure this relationship by conducting organizational training survey at two different times. The research resulted that the type of training has some effect over the productivity (Black and Lynch, 2001). One other research was conducted to find out the influencing factors of productivity in United States steel mills (Ichniowski, Shaw, and Prennushi, 1997). According to a study, French and Swedish organizations have $82 \%$ and $67 \%$ returns on training respectively (Ballot, Fakhfakh, and Taymaz, 2002). The coefficient on workers skills and knowledge in productivity is high than twice (O'Mahony, 1998). In addition to this, there are some other papers that have searched the Human Capital impact directly on the measurement of productivity on the data of United States (Moretti, 2004) and on the British data (Haskel, Hawkes, and Pereira, 2003). The above literature makes us to draw a positive relationship between on-job- Training and productivity. In addition, we will also assume to extend this idea to a positive relationship of Productivity and Organizational performance.

H7: On the job training, have positive effects on Productivity of Employees.

H8: Productivity affects the organizational performance positively.

Return on Training Investment: In most of the countries in the world, there is an increase in the need of training employees due to modern jobs are introduced and new plants are established and skill improvement is important for developing the core competencies required to keep a productive workers. Organization use to arrange training program for its less competent employees. Organizations are continuously increasing the budget of training each year. The training expenditure growth rate in USA is $5 \%$ in the last ten years (Industry Report, 2002) and it is increased to $10 \%$ in the years 2000 and 2001. Many organization values the training investment more than the cost. According to a study, the value of training investment is understood by the companies and so they invest money even in a financial decline (Kleiman, 2002). Return on training investment is one of the emerging topics in the world. In early days, there was no evaluation of this investment and so a little accountability of the trainers. A study has been conducted in more than thirty-five countries in different organization and address the most important trends of this area that have a notable impact on the accountability (Phillips and Guadet, 2003). It is a natural phenomenon that accountability increases with the increase of expenditure and often results to the development of rate on Investment process. Due to its importance, there are various researches specifying the use, interest and methodology of ROTI. A survey was conducted by the American Society for Training and Development and found out that the most important and global issue, which has been facing by the human resource managers, is the development of the training investment return (Van-Buren, 2002). A couple of researches have been conducted simultaneously show the improvement of return on investment and its problems. Out of these researches, a 
comprehensive research was carried out by corporate leadership Council, by involving 278 various organizations, which clarifies the ultimate interest in Rate of Investment in order to find out the main metrics preferred and used by the practitioners of Training (Drimmer, 2002). Managers are well aware from all the level of an organization, and know much about the operational and economic concerns, which make them to take a production approach to training with rate of investment as a part of their plan (Van and Trolley, 1999). ROI is a familiar term and measuring the Rate of return on Training Investment is becoming a hot discussion area day by day. In one survey, its measuring was repeatedly ratted the most recent topic among the international organizations members (Phillips, and Gaudet. 2003). The given literature is summarized in the following assumptions.

H9: On-job-training has a positive effect on ROTI.

H10: ROTI has a positive relationship with Organization's over all performance.

Organizational overall Performance: As we have discussed earlier in this research that due to new technology and competitions, organizations needs to train their employees and make them aware with the modern technology, new jobs and competitions. This will not only make the employees competent but will give the organization quite satisfactory outcomes also. Due to this, organizations usually do invest money in training to get better performance (Alliger, Tannenbaum, Bennett, Traver, \& Shortland, 1997; Kozlowski, Brown, Weissbein, Cannon-Bowers, \& Salas, 2000). The main aim of training is to give the new employees or low skilled employees the basic knowledge and skills to do the job in a better way (Fitzgerald, 1992). This is because all workers are not the same and some further skills and knowledge is required to the less competent workers. Investment in training of human capital is strongly connected to the productivity etc (Becker, 1962). Organizations know that training investment could increase the productivity; decreases turnover rate and so increase improve the firm's performance (Huselid, 1995; Martocchio \& Baldwin, 1997; Salas \& CannonBowers, 2000). One of the model, which interrelate the training, and organizational over all performance says that individual performance is increased with training and human recourse management activities, which is surly further lead to higher organizational performance (Devanna, Formbrun and Tichy, 1984). A more valuable research, which articulates easily and empirically the correlation between human Resource management policies and firm's performance was also proposed. According to this model employee, commitment has a strong impact on firm performance, which is concerned to link the employee's goals with the goals of the firms. So, if the training policy is enough mature to proper integrate the HRM activities and policies, it will increase worker commitment. This will result decrease in turnover rate and high job performance, which in turn leads to organizational overall performance (Guest, 1987). Another study presented six models, out of which three explains the interrelationship of training and performance of organization. This is based on the rationality of HR activities, organizational strategy and organizational outcomes (Wright and McMahan, 1992). Out of these three the first model, resource (Barney, 1991) based model summarizes that training improve skills of workers which in turn leads to high performance of organizational. Second model explains the behavioral perspective of training as it has a mediating role between firm strategy and performance (Schuler, 1989). This models states that training should promote attitudes and behavior of employees, which could increase the performance of the firm. Third model focuses on the environmental inputs like HR skills and abilities and its output like job satisfaction, turnover intention and productivity. So training is needed to develop and improve employee's skills, knowledge, abilities and behavior, which have a positive impact over the outcomes of organizations.

\section{Methodology}

In current era, every organization wants to make its employees skillful to compete in the changing environment and fulfill the organizational needs. For this purpose, almost all organizations conduct trainings. Organizations also hire trainers and pay them large amount of money. This research is about trainings and return on training investment. For this research, we have done literature survey and conducted it in below manner. In literature review, we have presented different reasons together with references from previous researches to conduct this research. In order to get the goal successfully the author conducted research survey to study deeply the variables between training and performance of organization. Questionnaire survey technique was used to collect data. 
Research Design: We have used hypotheses testing method for getting result. We have tested different relations among the variable we desired for the research result. To get the data we had distributed the questionnaire in PTCL and PEMRA. Every employee was appreciated for participation in the survey. It was hard to distribute the questionnaire in all places where the office of the selected organizations exists; therefore, offices at Islamabad and Rawalpindi were chosen for the research survey. One other reason was cost also. We had distributed almost 250 questionnaires out of which 193 were valid the remaining were not filled properly or the employees did not return it back. The respondent response rate was $77 \%$.

Development of the Questionnaires: We have developed the questionnaire for the research after the literature survey, which were closed ended and arranged in a manner suggest by literature survey. For the planned relationship of the study, the questionnaires were properly arranged to get the valuable outcome. There were total thirty-six questions and seven variables in the questionnaire. The questions were asked irrespective to employees group and gender.

\section{Structured Model:-}

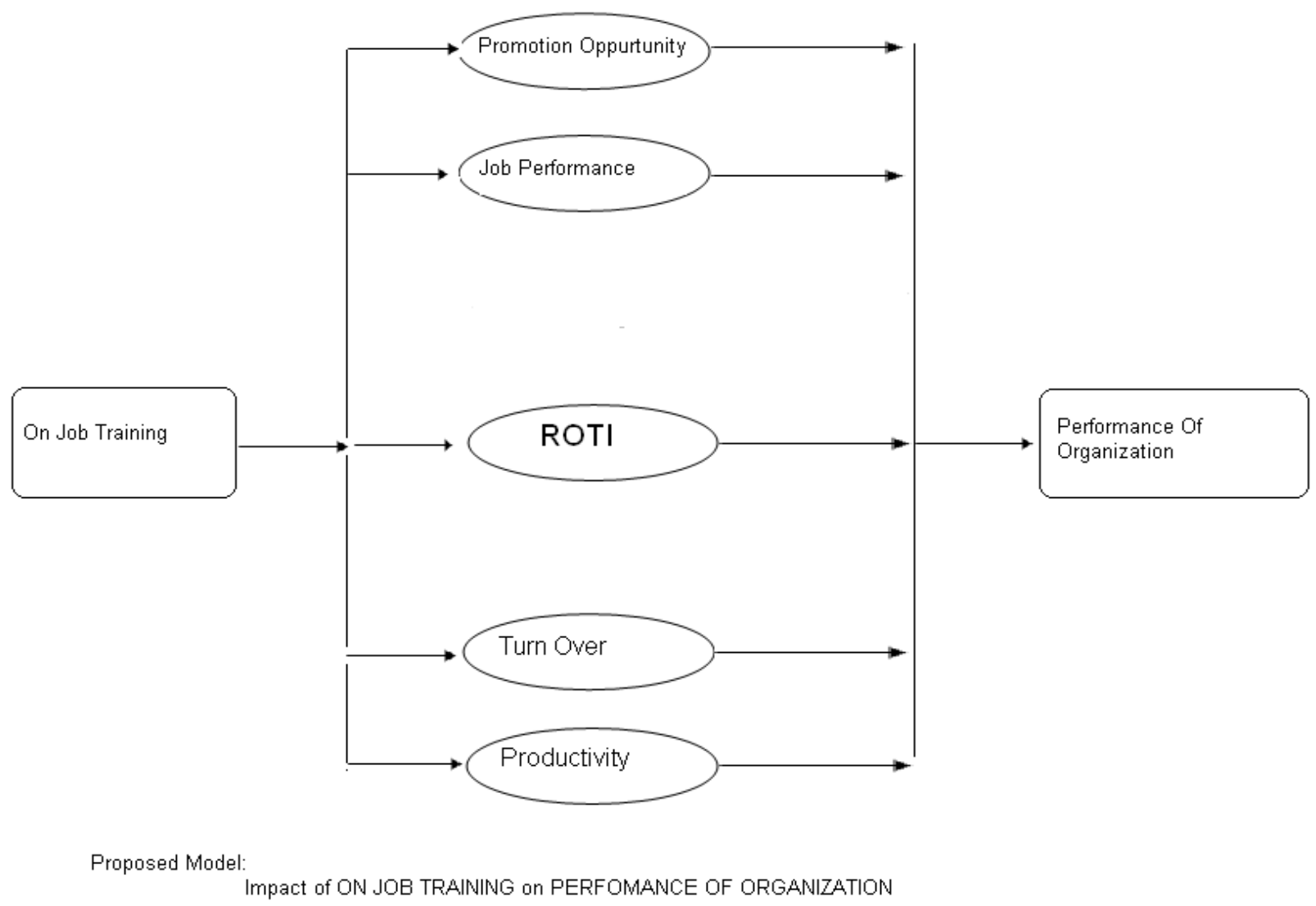

The Pilot Study: The finalized questionnaire were distributed among the employees of the selected organization and collected. The questionnaire was found fit and appropriated for the research. The data collected was just used once before the research.

Sampling: The data had been collected from employees of PTCL and PEMRA. The employees for filling out the questionnaire were selected through simple random sampling. This made our research more reliable and accurate. The author did not care for position, grade or gender of the respondent. This made the research 
more valuable and accurate in its results.

Data Collection: The employees were randomly chosen from PTCL and PEMRA headquarter Islamabad. The employees were considered to fill out the questionnaire during working hours also; they were not bound from taking the questionnaire to home. The participants were requested to return the questionnaire by the given date after a week as per schedule.

\section{Results and Analysis}

Reliability Test: After collecting the questionnaire, I have tested the data through SPSS tool for its reliability. The Cronbach's Alpha value for this research data is 0.887 .

One way ANOVA: The author also applied the ANOVA test for his research data for finding the difference of gender responses. The F-value and Significance value for Training, Productivity, Job Performance, Turnover, and Return on Training Investment, Organizational Productivity and Over all Performance of Organization are 0.138 and $0.710,0.206$ and $0.650,0.145$ and $0.704,0.081$ and $0.776,0.792$ and 0.35 , and 0.82 and 774 respectively. It means that there is no significant vale, which clarifies that the response of male and female are same as show in the following table.

Table 1: ANOVA Test

\begin{tabular}{|c|c|c|c|c|c|}
\hline & $\begin{array}{l}\text { Sum of } \\
\text { Squares }\end{array}$ & Df & Mean Square & $\mathbf{F}$ & Sig. \\
\hline Between Groups & .085 & 1 & .085 & .138 & .710 \\
\hline Within Groups & 117.354 & 191 & .614 & & \\
\hline Total & 117.440 & 192 & & & \\
\hline Between Groups & .082 & 1 & .082 & .206 & .650 \\
\hline Within Groups & 76.132 & 191 & .399 & & \\
\hline Total & 76.214 & 192 & & & \\
\hline Between Groups & .044 & 1 & .044 & .145 & .704 \\
\hline Within Groups & 58.157 & 191 & .304 & & \\
\hline Total & 58.201 & 192 & & & \\
\hline Between Groups & .023 & 1 & .023 & .081 & .776 \\
\hline Within Groups & 55.219 & 191 & .289 & & \\
\hline Total & 55.242 & 192 & & & \\
\hline Between Groups & .167 & 1 & .167 & .792 & .375 \\
\hline Within Groups & 40.246 & 191 & .211 & & \\
\hline Total & 40.413 & 192 & & & \\
\hline Within Groups & 129.193 & 191 & .676 & & \\
\hline Total & 129.591 & 192 & & & \\
\hline Between Groups & .120 & 1 & .120 & .372 & .543 \\
\hline Within Groups & 61.642 & 191 & .323 & & \\
\hline Total & 61.762 & 192 & & & \\
\hline Between Groups & .035 & 1 & .035 & .082 & .774 \\
\hline Within Groups & 82.135 & 191 & .430 & & \\
\hline Total & 82.170 & 192 & & & \\
\hline
\end{tabular}

Correlation Analysis: The correlation Statistics of the variables is given in the following table. It was found that the entire variable is well correlated with each other. The value of correlation and significance for between Training and Productivity, Job Performance, Turnover, Return on Training Investment, and Organizational Productivity are 0.40 and $p=0.581,0.402\left(^{* *}\right)$ and $p=0.000,0.282\left(^{* *}\right)$ and $p=0.000,0.380\left(^{* *}\right.$ ) and $p=0.000$, and 0.535 and $p=0.000$. The correlation statistics of Productivity, Job Performance, Turnover, 
Return on Training Investment, and Organizational Productivity with Over all Performance of Organization are $0.248\left(^{* *}\right)$ and $\mathrm{p}=0.001,0.094$ and $\mathrm{p}=0.196,0.207\left(^{* *}\right)$ and $\mathrm{p}=0.004,0.245\left(^{* *}\right)$ and $\mathrm{p}=0.002$, and $0.389\left(^{* *}\right.$ ) and 0.000 . All the correlation in this case is effective except Job performance, which has not effective values.

Regression Analysis: The regression analysis shows that Training has reliable relationship with Productivity, Job Performance, Job Skills, Promotion Opportunity, Turn Over and rate of ROTI. Such a relationship observed in the next part of the model, which demonstrates the reliability of the Productivity, Job Performance, Job Skills, Promotion Opportunity, Turn Over and rate of ROTI relationship with the Performance of Organization. All of the important values from the regression analysis are given below.

Table 2: Correlations

\begin{tabular}{|c|c|c|c|c|c|c|c|c|}
\hline & & $\mathbf{T}$ & $\mathbf{P}$ & $\mathbf{J P}$ & TRO & ROTI & PO & OP \\
\hline \multirow[t]{4}{*}{$\mathrm{T}$} & Pearson & & & & & & & \\
\hline & Correlation & 1 & & & & & & \\
\hline & Sig. (2-tailed) & & & & & & & \\
\hline & $\mathrm{N}$ & 193 & & & & & & \\
\hline \multirow[t]{4}{*}{$\mathrm{P}$} & Pearson & & & & & & & \\
\hline & Correlation & .040 & 1 & & & & & \\
\hline & Sig. (2-tailed) & .581 & & & & & & \\
\hline & $\mathrm{N}$ & 193 & 193 & & & & & \\
\hline \multirow[t]{4}{*}{ JP } & Pearson & & & & & & & \\
\hline & Correlation & $.402\left(^{* *}\right)$ & $.773(* *)$ & 1 & & & & \\
\hline & Sig. (2-tailed) & .000 & .000 & & & & & \\
\hline & $\mathrm{N}$ & 193 & 193 & 193 & & & & \\
\hline \multirow[t]{4}{*}{ TRO } & Pearson & & & & & & & \\
\hline & Correlation & $.282(* *)$ & $.707(* *)$ & $.827(* *)$ & 1 & & & \\
\hline & Sig. (2-tailed) & .000 & .000 & .000 & & & & \\
\hline & $\mathrm{N}$ & 193 & 193 & 193 & 193 & & & \\
\hline ROT & Pearson & & & & & & & \\
\hline \multirow[t]{3}{*}{ I } & Correlation & $.380(* *)$ & $.491(* *)$ & $.777(* *)$ & $.683(* *)$ & 1 & & \\
\hline & Sig. (2-tailed) & .000 & .000 & .000 & .000 & & & \\
\hline & $\mathrm{N}$ & 193 & 193 & 193 & 193 & 193 & & \\
\hline \multirow[t]{4}{*}{$\mathrm{PO}$} & Pearson & & & & & & & \\
\hline & Correlation & $.535\left(^{* *}\right)$ & $.334(* *)$ & $.558\left(^{* *}\right)$ & $.407\left(^{* *}\right)$ & $.509\left(^{* *}\right)$ & 1 & \\
\hline & Sig. (2-tailed) & .000 & .000 & .000 & .000 & .000 & & \\
\hline & $\mathrm{N}$ & 193 & 193 & 193 & 193 & 193 & 193 & \\
\hline \multirow[t]{4}{*}{$\mathrm{OP}$} & Pearson & & & & & & & \\
\hline & Correlation & .093 & $.248\left(^{* *}\right)$ & .094 & $.207\left(^{* *}\right)$ & .085 & $.389\left(^{* *}\right)$ & 1 \\
\hline & Sig. (2-tailed) & .199 & .001 & .196 & .004 & .240 & .000 & \\
\hline & $\mathrm{N}$ & 193 & 193 & 193 & 193 & 193 & 193 & 193 \\
\hline
\end{tabular}

** Correlation is significant at the 0.01 level (2-tailed).

Table 3: Training and Promotion Opportunity

\begin{tabular}{cllllllll}
\hline Model & B & Std. Error & T-Statistics & Sig. & $\begin{array}{l}\text { R- } \\
\text { Square }\end{array}$ & $\begin{array}{l}\text { F- } \\
\text { Statistics }\end{array}$ & P-value \\
\hline & (Constant) & 1.674 & .203 & 8.268 & .000 & 0.268 & 76.504 & 0.000 \\
T & .496 & .057 & 8.747 & .000 & & & \\
\hline
\end{tabular}

Predictors: (Constant), $T$

$b$ Dependent Variable: $P O$ 
Table 4: Training and Job Performance

\begin{tabular}{clllllll}
\hline Model & B & Std. Error & $\begin{array}{l}\text { T- } \\
\text { Statistics }\end{array}$ & Sig. & R-Square & $\begin{array}{l}\text { F- } \\
\text { Statistics }\end{array}$ & P-value \\
\hline (Constant) & 2.642 & .187 & 14.128 & .000 & 0.162 & 36.841 & 0.000 \\
T & .318 & .052 & 6.070 & .000 & & & \\
\hline
\end{tabular}

Predictors: (Constant), $T$

$b$ Dependent Variable: JP

The above table shows values for the regression analysis of Training and Promotion Opportunity, which has the R-square value of 0.268 , and F-value 76.504 . This presents that the relationship is significant and positive between the variables. The above-mentioned table demonstrates value for analysis of Training and Job Performance having R-Square value 0.162 and F-value 36.841 . The result shows positive significant relation between the variable.

Table 5: Training and Turnover

\begin{tabular}{clllllll}
\hline Model & B & Std. Error & T-Statistics & Sig. & R-Square & F-Statistics & P-value \\
\hline (Constant) & 2.868 & .196 & 17.641 & .000 & 0.079 & 16.464 & 0.000 \\
$\mathrm{~T}$ & .223 & .055 & 5.860 & .000 & & & \\
\hline
\end{tabular}

a Constant), T, $b$ Dependent Variable: TRO

The above table shows assessment of Training and Turnover with R-value 0.079 and F-value 16.464 . The relationship is significant and positive.

Table 6: Training and Productivity

\begin{tabular}{clllllll}
\hline Model & B & Std. Error & T-Statistics & Sig. & R-Square & F-Statistics & P-value \\
\hline (Constant) & 2.417 & .320 & 7.551 & .000 & 0.082 & 18.765 & 0.000 \\
T & .371 & .090 & 4.138 & .000 & & & \\
\hline
\end{tabular}

Predictors: (Constant), $T, b$ Dependent Variable: $P$

The aforementioned table reveals regression values for Training and Individual Productivity. The value for FStatistics and R-square is 18.765 and 0.082 respectively, which resemble positive and significant relation between the variables.

Table 7: Training and Rate of Training Investment

\begin{tabular}{clllllll}
\hline Model & B & Std. Error & T-Statistics & Sig. & R-Square & F-Statistics & P-value \\
\hline (Constant) & 2.680 & .152 & 17.641 & .000 & 0.145 & 32.268 & 0.000 \\
T & .241 & .043 & 5.860 & .000 & & & \\
\hline
\end{tabular}

Predictors: (Constant), $T, b$ Dependent Variable: ROTI

The values for R-square and F-statistics for Training and Rate of Training Investment Return are 0.145 and 32.268 respectively. It means that the relationship is positive and significant as mentioned in above table.

Table 8: Productivity, Organizational Performance, Promotion Opportunity, Job Performance and Performance of Organization, Modal Summary:

\begin{tabular}{llllllll}
\hline Model & B & Std. Error & T-Statistics & Sig. & R-Square & F-Statistics & P-value \\
\hline (Constant) & 1.139 & .797 & 1.430 & .155 & 0.350 & 16.695 & 0.000 \\
P & .969 & .190 & 5.113 & .000 & & & \\
JP & -2.293 & .363 & 6.325 & .000 & & & \\
TRO & .861 & .313 & 2.746 & .007 & & & \\
ROTI & .058 & .291 & .245 & .002 & & & \\
PO & 1.137 & .184 & 6.190 & .000 & & & \\
\hline
\end{tabular}

Predictors: (Constant), PO, P, ROTI, TRO, JP

$b$ Dependent Variable: $O P$ 
Lastly the regression analysis of Productivity, Organizational Performance, Promotion Opportunity, Job Performance with Performance of Organization shows that their relationship is positive as well as significant with $0.350 \mathrm{R}$-square value and $16.67 \mathrm{~F}$-statistics value. The above values summaries that all the dependent and independent variables have strong or weak but positive and significant relationship with each other, whenever they are considered for a relationship. It means that their consideration in the research is beneficial and worthy. The following conclusion was drawn from correlation and regression analysis of the research data.

\section{Conclusion}

The conclusion of the research articles is summarized in the following lines. Training is necessary for the existence of organizations and may be called as its soul. The research shows that employees know the importance training and relate it with their Productivity. They also agree with the positive impact of Training over Organizational Performance. More over they are happy to get advanced Training for their Promotion, which they believe necessary for it. As Training increases Job Skills, so the Job performance has also strong relationship with it. The Return on Training Investment is low as compared to its output, which was noted from the employee's response. In short, Training plays a vital role in the betterment of worker and over all productivity of organizations. In Pakistani scenario, it would be better if said that organizations should maintains check and balance over the Training contents and cost to make it more beneficial and productive.

Recommendations: After getting the results from the research analysis, the following recommendations had been made specifically for telecommunication Industry and all other organizations and general:

- It is highly recommended that organizations specifically in telecommunication sector and other sector organization in general should maintain its culture of training for making their organization more productive and competitive in the market.

- It is also strongly recommended that the arrangement of training should be made proper with the minimum possible expenditure and having more output.

- It is greatly recommended that all organizations should arrange training for each level employee.

- It is recommended that training should be given to the employees in such a way that they consider it healthy for their skills development, position advancement and productive for their organization.

- Training material should be limited to their job and organization. Extra materials should be avoided from the Training.

\section{References}

Alliger, G. M., Tannenbaum, S. I., Bennett, W., Traver, H. \& Shortland, A. (1997). A meta-analysis on the relations among training criteria. Personnel Psychology, 50, 341-358.

Analysis in the Learning Function. (2002).Washington DC: Corporate Executive Board, 2002. Industry Report 2002. Training, 34(10), 33-75.

Arthur, J. (1994). Effects of human resource systems on manufacturing performance and turnover. Academy of Management Journal, 37, 670-687.

Baldwin, T. T., Magjuka, R. J. \& Loher, B. T. (1991). The perils of participation: Effects of choice of training on trainee motivation and learning. Personnel Psychology, 44, 51-65.

Ballot, G., Fakhfakh, F. \& Taymaz, E. (2002). Who benefits from training and R\&D: the firm or the workers? Economic Research Center Working Papers in Economics 02/01, Middle East Technical University, Ankara, Turkey.

Ballot, G., Fakhfakh, F. \& Taymaz, E. (1998). Formation continues, recherché et développement, et performance des enterprises. Formation Emploi, 64, 43-55.

Barron, J., Black, D. \& Loewenstein, M. (1993). Gender differences in training, capital and wages. Journal of Human Resources, 28(2), 343-364.

Barney, J. (1991). Firm resources and sustained competitive advantage. Journal of Management, 17(1), 99120.

Baumgartel, H. \& Jeanpierre, F. (1972). Applying new knowledge in the back-home setting: A study of Indian 
managers' adoptive efforts. Journal of Applied Behavioral Science, 8, 674-694.

Becker, G. S. (1962). Investment in human capital: A theoretical analysis. Journal of Political Economy, 70(1), 9-49.

Black, S. E. \& Lynch, L. M. (2001). How to compete: the impact of workplace practices and information technology on productivity. Review of Economics and Statistics, 83, 434-445.

Carneiro, P. \& Heckman, J. (2003). Human Capital Policy published in J. Heckman and A. Krueger, Inequality in America: What Role for Human Capital Policy. MIT Press.

Cascio, W. F. (2000). Costing human resources: The financial impact of behavior in organizations (4th ed.). Boston: Kent.

Dearden, L., Reed, H. \& van Reenen, J. (2006). The impact of training on productivity and wages: Evidence from british panel data. Oxford Bulletin of economics and statistics, 68, 397-421.

Devanna, M. A., Fombrun, C. J. \& Tichy, N. M. (1984). A framework for strategic human resource management. In C. J. Fombrun, N. M. Tichy \& M. A. Devanna (Eds.) Strategic human resource management (33-55). New York, NY: Wiley.

Dohm, A. (2000). Gauging the labor force effects of retiring baby boomers. Monthly Labor Review, 123 (7), 1725.

Dohm, A. \& Shniper, L. (2007). Occupational employment projections to 2016. Monthly Labor Review, 130 (11), 86-125. http://www.bls.gov/opub/mlr/2007/11/art5full.pdf (accessed January 14, 2009).

Fitzgerald, W. (1992). Training versus development. Training and Development, 46(5), 81-84.

Gaertner, S. (2000). Structural determinants of job satisfaction and organizational commitment in turnover models. Human Resource Management Review, 9(4), 479-493.

Guest, D. E. (1987). Human resource management and industrial relations. Journal of Management Studies, 24(5), 503-521.

Haskel, J., Hawkes, D. \& Pereira, S. (2003). Skills, productivity in the UK using matched establishment, worker and workforce data, Ceriba, Discussion Paper.

Holzer, H. (2007a). Investing in workforce development: Defining the business interest.

Holzer, H. \& Lerman, R. (2009). America's forgotten middle-skill jobs: Education and training requirements in the next decade and beyond. Washington, DC: The Workforce Alliance.

Holzer, H. \& Martinson, K. (2005). Can we improve job retention and advancement among low-income working parents? Paper prepared for the Working Families Roundtable, Washington, DC, and May 910.

Huselid, M. A. (1995). The impact of human resource management practices on turnover, productivity, and corporate financial performance. Academy of Management Journal, 38(3), 635-672.

Huselid, M., Jackson, S. \& Schuler, R. (1997). Technical and strategically human resource management effectiveness as determinants of Firm performance. Academy of Management Journal, 40, 171-188.

Ichniowski, C., Shaw, K. \& Prennushi, G. (1997). The effects of human resource management practices on productivity. American Economic Review, 87, 291-313.

Jong J. A. D., Leenders, F. J. \& Thijssen, J. G. (1999). HRD tasks of first-level managers. Workplace Learning, 11(5), 176-83.

Kim, S. (2002). Participative management and job satisfaction: Lessons for management leadership. Public Administration Review, 62, 231-241.

Kleiman, C. (2002). Smart Bosses Leave Training on the Budget, Chicago Tribune.

Kontoghiorghes, C. (2001). A holistic approach towards motivation to learn. Performance Improvement Quarterly, 14(4), 233-246.

Kozlowski, S., Brown, K., Weissbein, D., Cannon-Bowers, J. \& Salas, E. (2000). A multi-level approach to training effectiveness. In K. Klein, \& S. Kozlowski (Eds.), Multi-level theory, research, and methods in organizations: Foundations, extensions, and new directions (157-210).

Kraiger, K., McLinden, D. \& Casper, W. J. (2004). Collaborative planning for training impact. Human Resource Management, 43(4), 337-351.

Krueger, A. \& Rouse, C. (1998). The effects of workplace education on earnings, turnover and job performance, Journal of Labor Economics, 16, 61-94.

Kuchinke, K. P. (1996). Classification of human development in HRD. Organization Development Journal, 14 (1), 55-69.

Lev, B. (2001). Intangibles: Management, Measurement, and Reporting. The Brookings Institution. 
Lynch, L. M. (1992). Private sector training and the earnings of young workers. American Economic Review, 82, 299-312.

Macguire, S., Freely, J., Clymer, C. \& Conway, M. (2009). Job training that works: Findings from the Sectoral Employment Impact Study. Philadelphia, PA: Public Private Ventures.

Martocchio, J. J. \& Baldwin, T. T. (1997). The evolution of strategic organizational training. In R. G. Ferris (Ed.). Research in Personnel and Human Resource Management, 15, 1-46. Greenwich, CT: JAI.

Moretti, E. (2004). Workers education, spillovers and productivity: evidence from Plant-Level Production Functions. American Economic Review, 94, 656-690.

Noe, R. A. (1986). Trainee attributes and attitudes: Neglected influences in training effectiveness. Academy of Management Review, 11, 736-749.

O'Mahony, M. (1998). Anglo-German productivity differences: the role of broad capital. Bulletin of Economic Research, 50, 19-36.

Parent, D. (1999). Wages and mobility: The impact of employer provided training. Journal of Labor Economics 17, 298-317.

Phillips, J. J. \& Gaudet, C. (2003). HRD Trends Worldwide: Shared Solutions to Compete in a Global Economy, 2nd ed. Boston, MA: Butterworth-Heinemann (In press).

Sablynski, C. J., Lee, T. W., Mitchell, T. R., Burton, J. P. \& Holtom, B. (2002). Turnover: An integration of Lee and Mitchell's unfolding model and job embeddedness construct with Hulin's withdrawal construct. In J. Brett, \& F. Drasgow (Eds.), The psychology of work. Mahwah, NJ: Erlbaum.

Salas, E. \& Cannon-Bowers, J. A. (2001). The science of training: A decade of progress. Annual Review of Psychology, 52, 471-499.

Salas, E. \& Cannon-Bowers, J. A. (2000). The anatomy of team training. In S. Tobias \& D. Fletcher (Eds.), Training and retraining: A handbook for business, industry, government and the military (312-335). Farmington Hills, MI: Macmillan.

Salas, E., Cannon-Bowers, J., Rhodenizer, L. \& Bowers, C. (1999). Training in organizations. Research in Personnel and Human Resources Management, 17, 123-161.

Schuler, R. S. (1989). Strategic human resource management and industrial relations. Human Relations, 42(2), 157-184.

Sturman, M. C., Trevor, C. O., Boudreau, J. W. \& Gerhart, B. (2003). Is it worth it to win the talent war? Evaluating the utility of performance-based pay. Personnel Psychology, 56(4), 997-1036.

Swanson, R. (1999). HRD theory, real or imagined? Human Resource Dev Int., 2(1), 2-5.

Trevor, C. O. (2001). Interactive effects among actual ease of movement determinants and job satisfaction in the prediction of voluntary turnover. Academy of Management Journal, 44, 621-638.

Van Adelsberg, D. \& Edward, A. T. (1999). Running Training like a Business: Delivering Unmistakable Value. San Francisco, CA: Berrett Koehler Publishers, Inc.

Van Buren, M. E. (2002). State of the Industry. Alexandria, VA: American Society for Training and Development.

VanWart, M., Cayer, N. J. \& Cork, S. (1993) .Handbook of training and development for the public sector. San Francisco, CA: Jossey-Bass.

Vaught, B. C., Hoy, F. \& Buchana, W. W. (1985). Employee development programs. London: Quorum Books.

Veum, J. (1995). Sources of training and their impact on wages. Industrial and Labor Relations, 48(4), 812826.

Watkins, K. E. \& Marsick, V. J. (Eds.). (2003). Make learning count! Diagnosing the learning culture in organizations. Advances in Developing Human Resources, 5 (2).

Wright, P. C. \& Geroy, G. D. (2001). Changing the mindset. International Journal of Human Resource Management, 12(4), 586-600.

Wright, P. M. \& McMahan, G. C. (1992). Theoretical perspectives for strategic human resource management. Journal of Management, 18(2), 295-320.

Zwick, T. (2006). The impact of training intensity on establishment productivity. Industrial Relations 45, 2646. 